\title{
Modified Phillipsite as a Novel Ion-Exchanger for Potassium Extraction from Seawater
}

\author{
Chunxia MENG ${ }^{1,2}$, Jin HOU ${ }^{1 *}$ \\ ${ }^{1}$ College of Chemistry and Chemical Engineering, Ocean University of China, Qingdao 266100, China \\ ${ }^{2}$ College of Environmental Science and Engineering, Ocean University of China, Qingdao 266100, China \\ crossref http://dx.doi.org/10.5755/j01.ms.25.4.19961
}

Received 16 January 2017; accepted 03 May 2018

\begin{abstract}
Template-free preparation of phillipsite as a novel $\mathrm{K}^{+}$ion-exchanger was studied systematically by hydrothermal synthesis. The alkalinity, dosage of water glass, dosage of $\mathrm{H}_{2} \mathrm{O}$, aging time, reaction temperature and time of hydrothermal synthesis were discussed in detail. The optimized material obtained about phillipsite through the synthesis and testing methods was performed. The $\mathrm{K}^{+}$ion-exchange capacity and selectivity coefficient were tested. The molar composition for preparing high performance phillipsite obtained was $2 \mathrm{~K}_{2} \mathrm{O}: 18 \mathrm{SiO}_{2}: \mathrm{Al}_{2} \mathrm{O}_{3}: 510 \mathrm{H}_{2} \mathrm{O}$ by optimizing synthetic conditions. The $\mathrm{K}^{+}$ion-exchange capacity of phillipsite was $57.3 \mathrm{mg} / \mathrm{g}$ in seawater. The $\mathrm{K}^{+}$selectivity coefficient was 88.6 in an equimolar $\mathrm{K}^{+}$and $\mathrm{Na}^{+}$mixed solution. Phillipsite can selectively capture $\mathrm{K}^{+}$over other ions, and therefore can be used for potassium extraction selectively from seawater. Phillipsite was characterized by X-ray diffraction (XRD), scanning electron microscopy (SEM) and energy-dispersive X-ray spectroscopy (EDS). The XRD pattern indicated that the synthetic zeolite was phillipsite. The phillipsite particles exhibited cross-like shape and the average particle size was about $2.5 \mu \mathrm{m}$. The synthetic phillipsite was mainly consisted of $\mathrm{Si}, \mathrm{Al}, \mathrm{K}$ and $\mathrm{O}$ elements.

Keywords: phillipsite, extracting potassium, ion-exchange, template-free, seawater.
\end{abstract}

\section{INTRODUCTION}

Zeolites are silicate crystalline materials with regular pore size and structure. They have been applied to ionexchange, adsorption and catalyst as one of the most important industrial raw materials [1-5]. Ion-exchange is an inherent feature for most of the zeolites. The high ionexchange capacity and selectivity to certain cations result in their wide application in adsorption and separation industry [6]. Actually phillipsites have been reported about their remarkable selectivities for certain cations. For instance, Colella reported the ion-exchange selectivity of three phillipsites towards $\mathrm{Cs}$ and $\mathrm{Sr}$ [7]. Pepe studied the mixed phillipsite and chabazite for removing $\mathrm{Ba}^{2+}$ by ionexchange [8].

Potassium is one of the essential nutrient elements for plant growth. Potassium resources are lacking on land, but enormous in seawater. So many public attentions have been gained for potassium extraction from seawater. At present, magnetic zeolite $\mathrm{P}$ and zeolite $\mathrm{W}$ have been reported as ion-exchangers for extracting potassium from seawater. Cao synthesized a series of magnetic zeolites $\mathrm{P}$ and studied the behavior of $\mathrm{K}^{+}$ion-exchange in seawater [9]. We reported the preparation of zeolite $\mathrm{W}$ and its $\mathrm{K}^{+}$ ion-exchange property in seawater [10].

In this work, phillipsite used as $\mathrm{K}^{+}$ion-exchanger was studied systematically. The alkalinity, dosage of water glass, dosage of $\mathrm{H}_{2} \mathrm{O}$, aging time, temperature and time of hydrothermal synthesis were discussed in detail. The optimal preparation method for high performance phillipsite was obtained by optimizing synthetic

\footnotetext{
* Corresponding author. Tel.: +86-532-66782223.

E-mail address: houjinqd@163.com (J. Hou)
}

conditions. Phillipsites were characterized by XRD, SEM and EDS.

\section{EXPERIMENTAL DETAILS}

\subsection{Materials}

The raw materials used included sodium aluminate $\left(\mathrm{NaAlO}_{2}\right.$, Aladdin), water glass $\left(27.8 \mathrm{wt} \% \mathrm{SiO}_{2}, 8.93 \mathrm{wt} \%\right.$ $\mathrm{Na}_{2} \mathrm{O}, 63.27$ wt $\% \mathrm{H}_{2} \mathrm{O}$, Dongyue), potassium hydroxide ( $\mathrm{KOH}$, Aladdin), ammonium chloride $\left(\mathrm{NH}_{4} \mathrm{Cl}\right.$, Aladdin) and sodium chloride ( $\mathrm{NaCl}$, Aladdin).

\subsection{Template-free synthesis of zeolite}

Template-free zeolite was synthesized from a synthetic solution by dissolving $\mathrm{NaAlO}_{2}$ and water glass in de-ionized water firstly, and then $\mathrm{KOH}$ solution was added to the mixture. The molar composition of the resulting synthetic gel was as follows: $\mathrm{xK}_{2} \mathrm{O}: \mathrm{ySiO}_{2}: \mathrm{Al}_{2} \mathrm{O}_{3}: \mathrm{zH}_{2} \mathrm{O}$. The gel was aged at a variable time at room temperature, and then transferred to a teflon-lined stainless steel autoclave and hydrothermally treated in an oven. Zeolite was recovered after hydrothermal treatment, washed with deionized water and dried at $110{ }^{\circ} \mathrm{C}$. Zeolite was successively modified with $20 \mathrm{wt} . \% \mathrm{NH}_{4} \mathrm{Cl}$ and $20 \mathrm{wt} . \%$ $\mathrm{NaCl}$ heated solutions for testing its $\mathrm{K}^{+}$ion-exchange property, and then modified zeolite was obtained.

\subsection{The $\mathrm{K}^{+}$ion-exchange equilibrium and ion- exchange capacity of zeolite in seawater}

$0.30 \mathrm{~g}$ modified zeolite was added to $200 \mathrm{~mL}$ seawater at room temperature. The concentrations of main cations in seawater were shown in Table 1 . The residual $\mathrm{K}^{+}$ concentration in the liquid phase was tested by atomic 
absorption spectrophotometer at a variable time. The equation for ion-exchange capacity is as follows:

$Q_{\mathrm{K}^{+}}=\frac{\left(c_{0}-c\right) \times V}{m}$,

where $Q_{\mathrm{K}^{+}}$stands for the $\mathrm{K}^{+}$ion-exchange capacity of zeolite $(\mathrm{mg} / \mathrm{g}) ; c_{0}$ is the $\mathrm{K}^{+}$concentration before ionexchange $(\mathrm{mg} / \mathrm{L}) ; c$ is the $\mathrm{K}^{+}$concentration after ionexchange $(\mathrm{mg} / \mathrm{L}) ; V$ represents the volume of seawater $(\mathrm{L})$; $m$ represents the dosages of zeolite $(\mathrm{g})$.

Table 1. Concentrations of main cations in seawater

\begin{tabular}{|c|c|c|}
\hline Ion & $\begin{array}{c}\text { Mass concentration, } \\
\mathrm{mg} \cdot \mathrm{mL}^{-1}\end{array}$ & $\begin{array}{c}\text { Molar concentration, } \\
\left.\mathrm{mmol} \cdot \mathrm{L}^{-1}\right)\end{array}$ \\
\hline $\mathrm{K}^{+}$ & 0.38 & 9.74 \\
\hline $\mathrm{Na}^{+}$ & 10.62 & 461.74 \\
\hline $\mathrm{Ca}^{2+}$ & 0.40 & 10.00 \\
\hline $\mathrm{Mg}^{2+}$ & 1.28 & 53.33 \\
\hline
\end{tabular}

\subsection{The $\mathrm{K}^{+}$selectivity coefficient of zeolite in an equimolar $\mathrm{K}^{+}$and $\mathrm{Na}^{+}$mixed solution}

$0.30 \mathrm{~g}$ modified zeolite was added to $200 \mathrm{~mL}$ equimolar $\mathrm{K}^{+}$and $\mathrm{Na}^{+}$mixed solution stirred continuously at room temperature. The contents of $\mathrm{K}^{+}$and $\mathrm{Na}^{+}$ions in the above mixed solution are both $10 \mathrm{mmol} / \mathrm{L}$. The concentrations of $\mathrm{K}^{+}$and $\mathrm{Na}^{+}$ions in the liquid phase were measured by atomic absorption spectrophotometer respectively after the liquid phase and solid phase were separated. Then the selectivity coefficient was calculated.

The ion-exchange selectivity is defined by the following equation:

$K_{\mathrm{t}}=A_{\mathrm{S}} B_{\mathrm{L}} / B_{\mathrm{S}} A_{\mathrm{L}}$,

where $K_{t}$ is the $\mathrm{K}^{+}$selectivity coefficient of zeolite; $A_{\mathrm{S}}$ and $B_{\mathrm{S}}$ represent the molar fraction of $\mathrm{K}^{+}$and $\mathrm{Na}^{+}$in the zeolite phase respectively; $A_{\mathrm{L}}$ and $B_{\mathrm{L}}$ represent the molar fraction of $\mathrm{K}^{+}$and $\mathrm{Na}^{+}$in the liquid phase respectively.

\subsection{Characterization}

The structure of synthetic zeolite was identified by Xray diffraction (XRD, D8-Advance, German Bruker). The image of synthetic zeolite was observed by scanning electron microscopy (SEM, S-4800, Japan Hitachi). Elemental analysis of synthetic zeolite was carried out by energy-dispersive X-ray spectroscopy (EDS, E-max, Japan Hitachi). The cation concentrations were tested by atomic absorption spectrophotometer (AAS, TAS-990, Beijing, China).

\section{RESULTS AND DISCUSSION}

\subsection{The $\mathrm{K}^{+}$ion-exchange equilibrium of zeolite in seawater}

The $\mathrm{K}^{+}$ion-exchange equilibrium curve of zeolite in seawater was tested. The $\mathrm{K}^{+}$ion-exchange capacities of zeolite in seawater at different time are shown in Fig. 1. The $\mathrm{K}^{+}$ion-exchange rate of zeolite was a fast process and reached an ion-exchange balance in about $20 \mathrm{~min}$. In order to ensure the complete ion-exchange, the ion-exchange time of subsequent experiments was set to $50 \mathrm{~min}$.

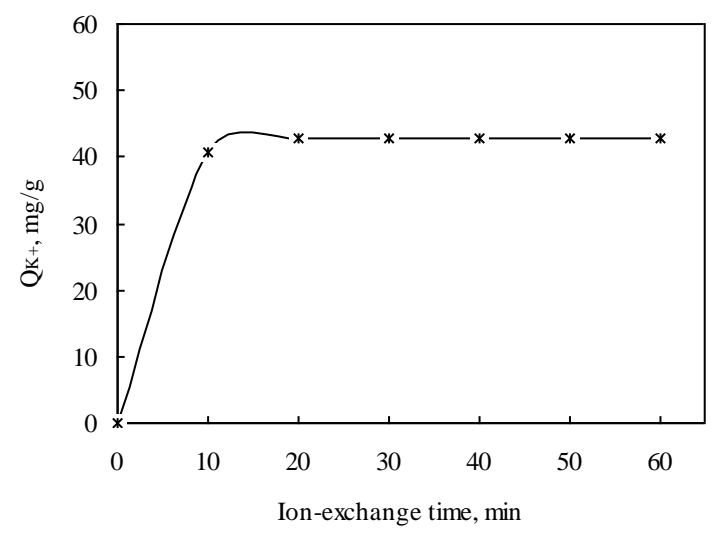

Fig. 1. The $\mathrm{K}^{+}$ion-exchange capacity of zeolite at different time in seawater

\subsection{The $\mathrm{K}^{+}$ion-exchange properties of zeolite in seawater}

\subsubsection{Effect of $\mathrm{K}_{2} \mathrm{O} / \mathrm{Al}_{2} \mathrm{O}_{3}$ molar ratio}

Five groups of experiments with various $\mathrm{K}_{2} \mathrm{O} / \mathrm{Al}_{2} \mathrm{O}_{3}$ molar ratios were completed to test the ion-exchange capacity. The resulting synthetic gel with molar ratio of $\mathrm{xK}_{2} \mathrm{O}: 18 \mathrm{SiO}_{2}: \mathrm{Al}_{2} \mathrm{O}_{3}: 570 \mathrm{H}_{2} \mathrm{O}$ was continuously aged for 10 hours, and then prepared by hydrothermal method at $160{ }^{\circ} \mathrm{C}$ for 24 hours. The $\mathrm{K}^{+}$ion-exchange capacities of prepared zeolites are shown in Fig. 2. The results showed that the $\mathrm{K}_{2} \mathrm{O} / \mathrm{Al}_{2} \mathrm{O}_{3}$ molar ratio of 2 was an optimum proportion for the $\mathrm{K}^{+}$ion-exchange capacity. The maximum value of ion-exchange capacity was $42.8 \mathrm{mg} / \mathrm{g}$. The additive of $\mathrm{KOH}$ provided not only an alkaline environment but also excess $\mathrm{K}^{+}$ion, which had a significant part in the synthesis of phillipsite.

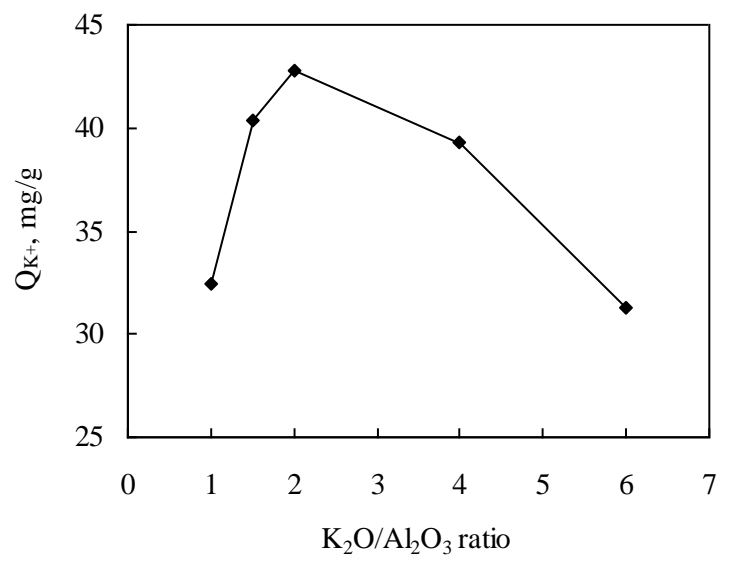

Fig. 2. The influence of $\mathrm{K}_{2} \mathrm{O} / \mathrm{Al}_{2} \mathrm{O}_{3}$ molar ratio on the ionexchange capacity

\subsubsection{Effect of $\mathrm{SiO}_{2} / \mathrm{Al}_{2} \mathrm{O}_{3}$ molar ratio}

Five sets of experiments with various $\mathrm{SiO}_{2} / \mathrm{Al}_{2} \mathrm{O}_{3}$ molar ratios were completed to test the influence of aluminum dosage on the ion-exchange capacity. The aluminum amount in the zeolite structure was directly proportional to the charge balance material, $\mathrm{K}^{+}$amount. Zeolites were gained in the synthetic gel with the molar ratio of $2 \mathrm{~K}_{2} \mathrm{O}: \mathrm{ySiO}_{2}: \mathrm{Al}_{2} \mathrm{O}_{3}: 570 \mathrm{H}_{2} \mathrm{O}$ after aged for 10 hours, and then prepared by hydrothermal method at 
$160{ }^{\circ} \mathrm{C}$ for 24 hours. Fig. 3 shows the $\mathrm{K}^{+}$ion-exchange capacities of synthetic zeolite with various $\mathrm{SiO}_{2} / \mathrm{Al}_{2} \mathrm{O}_{3}$ molar ratios. The results show that the $\mathrm{K}^{+}$ion-exchange capacity reached a maximum value when the $\mathrm{SiO}_{2} / \mathrm{Al}_{2} \mathrm{O}_{3}$ molar ratio is 18 . The optimum value of ion-exchange capacity is $42.8 \mathrm{mg} / \mathrm{g}$.

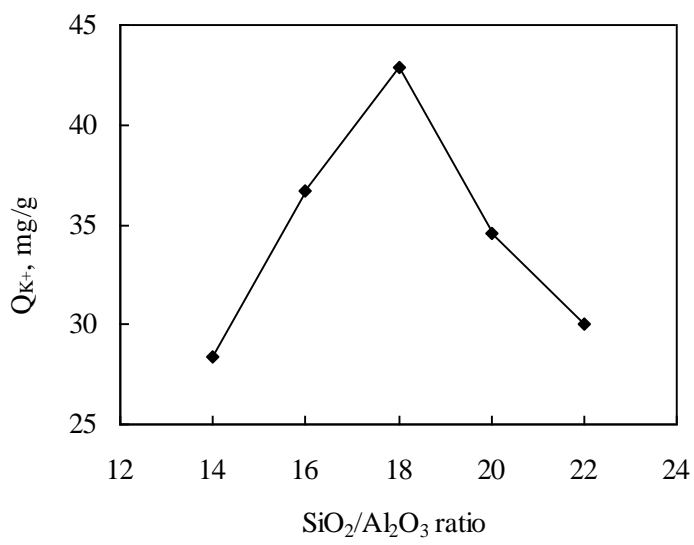

Fig. 3. The influence of $\mathrm{SiO}_{2} / \mathrm{Al}_{2} \mathrm{O}_{3}$ molar ratio on the ionexchange capacity

\subsubsection{Effect of $\mathrm{H}_{2} \mathrm{O} / \mathrm{Al}_{2} \mathrm{O}_{3}$ molar ratio}

Fig. 4 shows the $\mathrm{K}^{+}$ion-exchange capacities of zeolites received with various $\mathrm{H}_{2} \mathrm{O}$ dosages from $2 \mathrm{~K}_{2} \mathrm{O}: 18 \mathrm{SiO}_{2}: \mathrm{Al}_{2} \mathrm{O}_{3}: \mathrm{zH}_{2} \mathrm{O}$ after aged for 10 hours, and then prepared by hydrothermal method at $160{ }^{\circ} \mathrm{C}$ for 24 hours. The results show that the $\mathrm{K}^{+}$ion-exchange capacity reached a maximum value when the $\mathrm{H}_{2} \mathrm{O} / \mathrm{Al}_{2} \mathrm{O}_{3}$ molar ratio was 510 . The optimum value of ion-exchange capacity was $44.8 \mathrm{mg} / \mathrm{g}$. Kim reported that the less the amount of water, the faster the crystallization process [11]. This indicated that a short distance between nutrients in solution would improve the nucleation and further crystallization. However high concentration normally causes crystal aggregation.

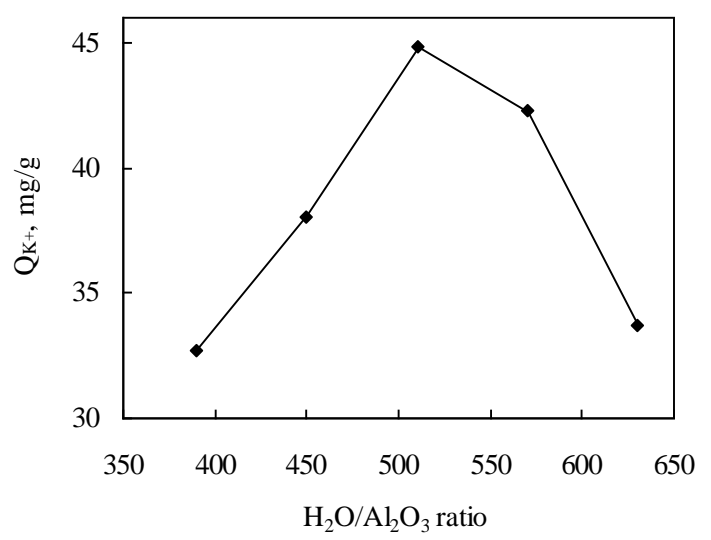

Fig. 4. The influence of $\mathrm{H}_{2} \mathrm{O} / \mathrm{Al}_{2} \mathrm{O}_{3}$ molar ratio on the ionexchange capacity

\subsubsection{Effect of aging time}

Fig. 5 shows the $\mathrm{K}^{+}$ion-exchange capacities of synthetic zeolite at various aging time. Zeolites were obtained in the synthetic gel with the molar composition of $2 \mathrm{~K}_{2} \mathrm{O}: 18 \mathrm{SiO}_{2}: \mathrm{Al}_{2} \mathrm{O}_{3}: 510 \mathrm{H}_{2} \mathrm{O}$ after aged, and then prepared by hydrothermal method at $160{ }^{\circ} \mathrm{C}$ for 24 hours. The result shows that the optimum aging time was 14 hours, so the optimum value of ion-exchange capacity was $53.1 \mathrm{mg} / \mathrm{g}$ at the above conditions. In general, Aging offers a required time to obtain the generation of crystalline nucleus with dissolution of solid fine particles, which resulted in the generation of smaller crystals. Aging at low temperature accelerated nucleation and rose the amount of crystalline nucleus in the preparation process.

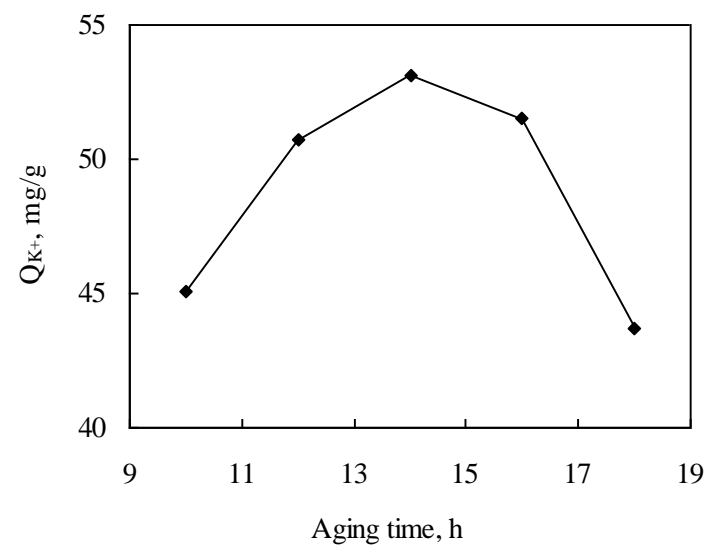

Fig. 5. The influence of various aging time on the ion-exchange capacity

\subsubsection{Effect of synthesis temperature}

Five groups of experiments at various synthesis temperature were completed to test the ion-exchange capacity. The resulting synthetic gel with molar ratio of $2 \mathrm{~K}_{2} \mathrm{O}: 18 \mathrm{SiO}_{2}: \mathrm{Al}_{2} \mathrm{O}_{3}: 510 \mathrm{H}_{2} \mathrm{O}$ was continuously aged for 14 hours, and then prepared by hydrothermal method for 24 hours. The $\mathrm{K}^{+}$ion-exchange capacities of prepared zeolites are shown in Fig. 6. The results show that the preferred synthetic temperature was $140^{\circ} \mathrm{C}$, and the optimum value of $\mathrm{K}^{+}$ion-exchange capacity was $57.3 \mathrm{mg} / \mathrm{g}$. The high temperature could enhance concentration of reactants in synthetic gel and was also propitious to crystallization.

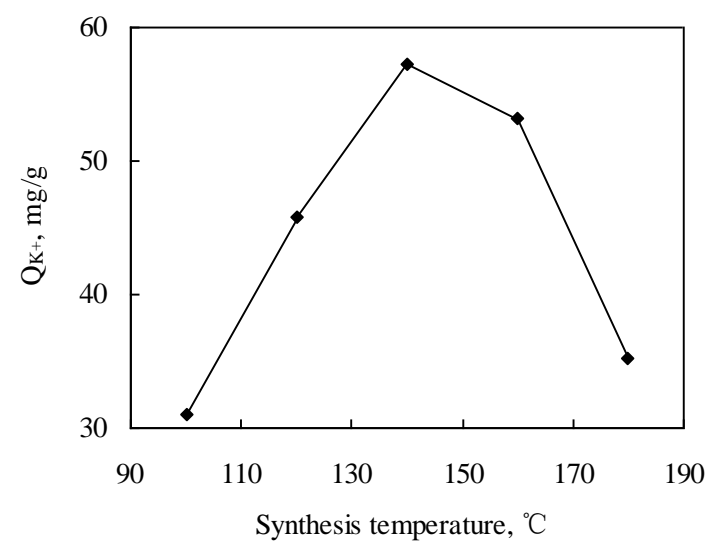

Fig. 6. The influence of various synthetic temperature on the ion-exchange capacity

\subsubsection{Effect of synthesis time}

Five groups of experiments at various synthesis time were completed to test the ion-exchange capacity. The 
resulting synthetic gel with molar ratio of $2 \mathrm{~K}_{2} \mathrm{O}: 18 \mathrm{SiO}_{2}: \mathrm{Al}_{2} \mathrm{O}_{3}: 510 \mathrm{H}_{2} \mathrm{O}$ was continuously aged for 14 hours, and then prepared by hydrothermal method at $140{ }^{\circ} \mathrm{C}$. The $\mathrm{K}^{+}$ion-exchange capacities of prepared zeolites are shown in Fig. 7. The results show that the preferable synthetic time was 24 hours, and the optimum value of $\mathrm{K}^{+}$ion-exchange capacity was $57.3 \mathrm{mg} / \mathrm{g}$. However, the ion-exchange capacity of zeolite $\mathrm{P}$ reported was $14.8 \mathrm{mg} / \mathrm{g}$ [9]. $\mathrm{K}^{+}$ion-exchange capacity would reduce when the prepared time was too long or too short. A short prepared time led to incomplete crystal skeleton, and a long prepared time resulted in the formation of large crystal particles.

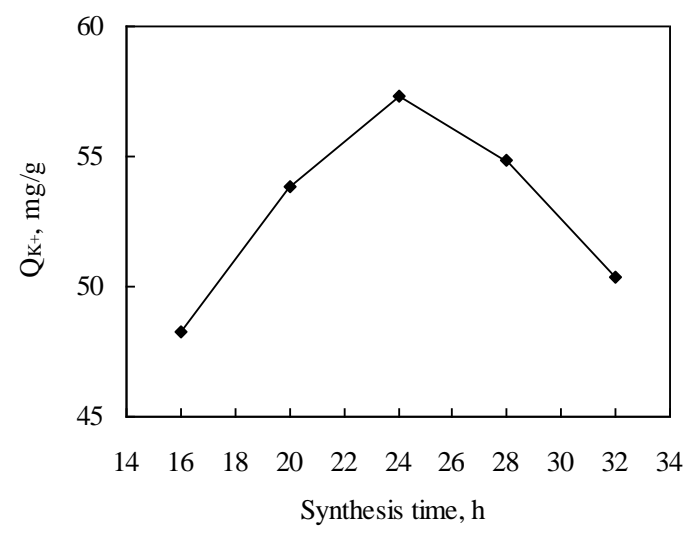

Fig. 7. The influence of different synthesis time on the ionexchange capacity

\subsection{The $\mathrm{K}^{+}$selectivity coefficient of zeolite in an equimolar $\mathrm{K}^{+}$and $\mathrm{Na}^{+}$mixed solution}

Zeolite tested was prepared according to the above optimal synthetic conditions, that is, the synthetic gel with the molar ratio of $2 \mathrm{~K}_{2} \mathrm{O}: 18 \mathrm{SiO}_{2}: \mathrm{Al}_{2} \mathrm{O}_{3}: 510 \mathrm{H}_{2} \mathrm{O}$ was aged for 14 hours at room temperature, and then prepared by hydrothermal method at $140{ }^{\circ} \mathrm{C}$ for 24 hours.

The $\mathrm{K}^{+}$selectivity coefficient of the zeolite is 88.6 in an equimolar $\mathrm{K}^{+}$and $\mathrm{Na}^{+}$mixed solution. So the zeolite can be used for extracting potassium selectively.

\subsection{Characterization of zeolite}

Zeolite characterized was synthesized according to the above optimal synthetic conditions. The molar ratio of synthetic gel was $2 \mathrm{~K}_{2} \mathrm{O}: 18 \mathrm{SiO}_{2}: \mathrm{Al}_{2} \mathrm{O}_{3}: 510 \mathrm{H}_{2} \mathrm{O}$, which was aged for 14 hours at room temperature, and then prepared by hydrothermal method at $140^{\circ} \mathrm{C}$ for 24 hours.

The XRD of synthetic zeolite was analyzed. The XRD pattern are shown in Fig. 8. The results indicate that the diffraction peaks $\left(2 \theta=10.85^{\circ}, 12.45^{\circ}, 16.60^{\circ}, 17.85^{\circ}\right.$, $21.00^{\circ}, 21.85^{\circ}, 23.55^{\circ}, 25.75^{\circ}, 26.85^{\circ}, 27.65^{\circ}, 28.10^{\circ}$, $29.85^{\circ}, 30.35^{\circ}, 32.75^{\circ}$ and $33.50^{\circ}$ ) correspond to the characteristic peaks of phillipsite $[12,13]$. So the synthetic zeolite is phillipsite.

The synthetic phillipsite was tested by SEM. Fig. 9 shows the SEM image for magnification of 10000 times. The morphology of phillipsite particles present cross-like shape. The average particle size is about $2.5 \mu \mathrm{m}$.
The element compositions of the synthetic phillipsite were analyzed by EDS. The results as shown in Fig. 10 indicate that phillipsite mainly consist of $\mathrm{Si}, \mathrm{Al}, \mathrm{K}$ and $\mathrm{O}$ elements. So the chemical constitution of synthetic phillipsite is Si-Al-K aluminosilicate.

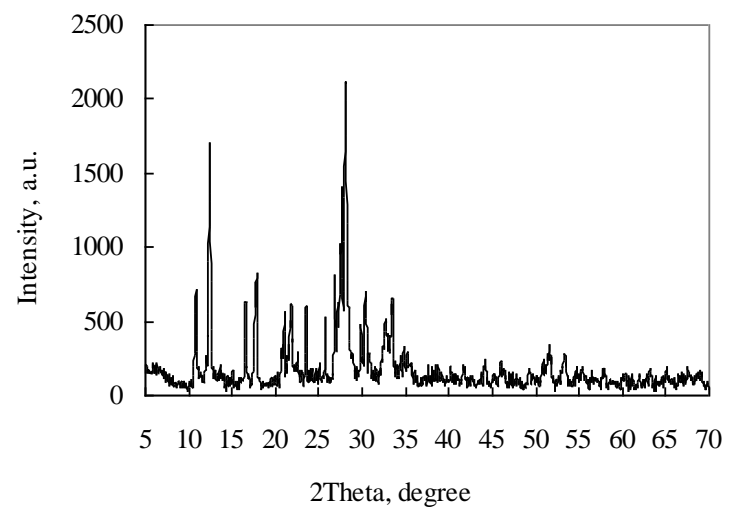

Fig. 8. XRD pattern of synthetic zeolite

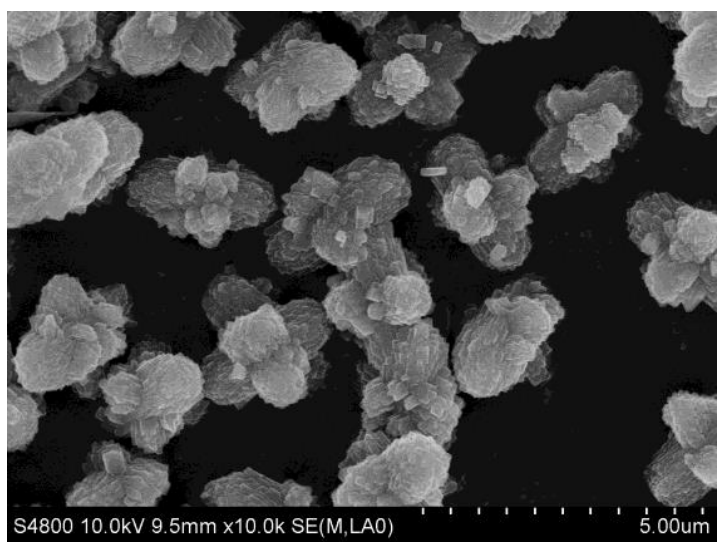

Fig. 9. SEM image of synthetic phillipsite

The element compositions of the synthetic phillipsite were analyzed by EDS. The results as shown in Fig. 10 indicate that phillipsite mainly consist of $\mathrm{Si}, \mathrm{Al}, \mathrm{K}$ and $\mathrm{O}$ elements. So the chemical constitution of synthetic phillipsite is $\mathrm{Si}-\mathrm{Al}-\mathrm{K}$ aluminosilicate.

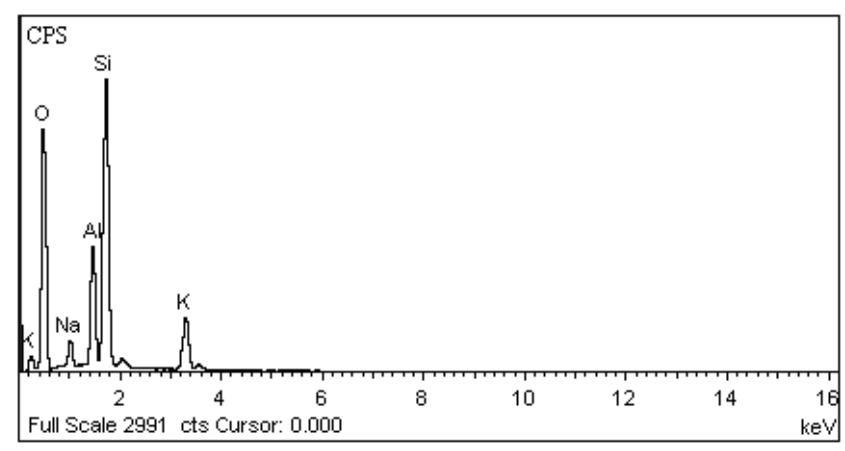

Fig. 10. EDS of synthetic phillipsite

\section{CONCLUSIONS}

Phillipsite was obtained with high $\mathrm{K}^{+}$ion-exchange performance. The optimal synthetic conditions were obtained. The molar ratio of synthetic gel was $2 \mathrm{~K}_{2} \mathrm{O}: 18 \mathrm{SiO}_{2}: \mathrm{Al}_{2} \mathrm{O}_{3}: 510 \mathrm{H}_{2} \mathrm{O}$, which was aged for 14 hours 
at room temperature, and then prepared by hydrothermal method at $140{ }^{\circ} \mathrm{C}$ for 24 hours. The $\mathrm{K}^{+}$ion-exchange capacity of phillipsite was $57.3 \mathrm{mg} / \mathrm{g}$, and the $\mathrm{K}^{+}$ selectivity coefficient was 88.6 in an equimolar $\mathrm{K}^{+}$and $\mathrm{Na}^{+}$ mixed solution at the optimal synthetic conditions. Phillipsite could selectively capture $\mathrm{K}^{+}$ion over other ions. So it could be used for extracting potassium selectively from seawater. The chemical constitution of synthetic phillipsite was Si-Al-K aluminosilicate.

Phillipsite was synthesized through high temperature and hydrothermal synthesis under the alkaline $(\mathrm{KOH})$ environment. The additive of $\mathrm{KOH}$ provided not only an alkaline environment but also excess $\mathrm{K}^{+}$ion, which had a significant part in the synthesis of phillipsite. Phillipsite had the memory function for $\mathrm{K}^{+}$ion introduced as a particular target ion in the preparation process, so the synthetic phillipsite had the special selective separation property for $\mathrm{K}^{+}$ion.

\section{Acknowledgments}

The authors thank the Natural Science Foundation of Shandong Province (NO. ZR2016BM06) for financial support.

\section{REFERENCES}

1. Jung, D., Lee, S., Na, K. $\mathrm{RuO}_{2}$ Supported $\mathrm{NaY}$ Zeolite Catalysts: Effect of Preparation Methods on Catalytic Performance During Aerobic Oxidation of Benzyl Alcohol Solid State Sciences 72 2017: pp. 150-155. https://doi.org/10.1016/j.solidstatesciences.2017.08.022

2. Lim, J.B., Jo, D.H., Hong, S.B. Palladium-Exchanged Small-Pore Zeolites with Different Cage Systems as Methane Combustion Catalysts Applied Catalysis B: Environmental 219 (15) 2017: pp. 55-162. https://doi.org/10.1016/j.apcatb.2017.07.032

3. Feng, P., Zhang, G.Q., Zang, K.L., Li, X.J., Xu, L.Y., Chen, X.F. A Theoretical Study on the Selective Adsorption Behavior of Dimethyl Ether and Carbon Monoxide on HFER Zeolites Chemical Physics Letters $684(16)$ 2017: pp. 79-284. https://doi.org/10.1016/j.cplett.2017.07.005

4. Hanim, S.A.M., Malek, N.A.N., Ibrahim, Z. Analyses of Surface Area, Porosity, Silver Release and Antibacterial Activity of Amine-Functionalized, Silver-Exchanged Zeolite $\mathrm{NaY}$ Vacuum 143 2017: pp. 344-347. https://doi.org/10.1016/j.vacuum.2017.06.038
5. He, Y.H., Lin, H., Dong, Y.B., Wang, L. Preferable Adsorption of Phosphate Using Lanthanum-Incorporated Porous Zeolite: Characteristics and Mechanism Applied Surface Science 426 2017: pp. 995-1004. https://doi.org/10.1016/j.apsusc.2017.07.272

6. Xue, Z.T., Li, Z.L., Ma, J.H., Bai, X., Kang, Y.H., Hao, W.M., Li, R.F. Effective Removal of $\mathrm{Mg}^{2+}$ and $\mathrm{Ca}^{2+}$ Ions by Mesoporous LTA Zeolite Desalination 341 2014: pp. $10-18$. https://doi.org/10.1016/j.desal.2014.02.025

7. Adabbo, M., Caputo, D., de Gennaro, B., Pansini, M., Colella, C. Ion Exchange Selectivity of Phillipsite for Cs and $\mathrm{Sr}$ as a Function of Framework Composition Microporous and Mesoporous Materials 28 (2) 1999: pp. 315-324.

8. Pepe, F., de Gennaro Aprea, B.P., Caputo, D. Natural Zeolites for Heavy Metals Removal from Aqueous Solutions: Modeling of the Fixed $\mathrm{Bed} \mathrm{Ba}^{2+} / \mathrm{Na}^{+}$IonExchange Process Using a Mixed Phillipsite/Chabazite-Rich Tuff Chemical Engineering Journal 219 2013: pp. $37-42$. https://doi.org/10.1016/j.cej.2012.12.075

9. Cao, J.L., Liu, X.W., Fu, R., Tan, Z.Y. Magnetic P Zeolites: Synthesis, Characterization and the Behavior in Potassium Extraction from Seawater Separation and Purification Technology 63 (1) 2008: pp. 92-100. https://doi.org/10.1016/j.seppur.2008.04.015

10. Hou, J., Yuan, J.S., Shang, R. Synthesis and Characterization of Zeolite $\mathrm{W}$ and its Ion-Exchange Properties to $\mathrm{K}^{+}$in Seawater Powder Technology 226 2012: pp. $222-224$. https://doi.org/10.1016/j.powtec.2012.04.046

11. Kim, S.D., Noh, S.H., Seong, K.H., Kim, W.J. Compositional and Kinetic Study on the Rapid Crystallization of ZSM-5 in the Absence of Organic Template under Stirring Microporous and Mesoporous Materials $72(1-3)$ 2004: pp. 185-192. https://doi.org/10.1016/j.micromeso.2004.04.024

12. Fukui, K., Katoh, M., Yamamoto, T., Yoshida, H. Utilization of $\mathrm{NaCl}$ for Phillipsite Synthesis from Fly Ash by Hydrothermal Treatment with Microwave Heating Advanced Powder Technology 20 (1) 2009: pp. 35-40. https://doi.org/10.1016/j.apt.2008.10.007

13. Rawajfih, Z., Mohammad, H.A., Nsour, N., Ibrahim, K. Study of Equilibrium and Thermodynamic Adsorption of $\alpha$ picoline, $\beta$-picoline, and $\gamma$-picoline by Jordanian Zeolites: Phillipsite and Faujasite Microporous and Mesoporous Materials 132 (3) 2010: pp. $401-408$. https://doi.org/10.1016/j.micromeso.2010.03.019 